\title{
ALGUNS RODRIGOS: RELATO DE VIAGEM SOBRE A FICCIONALIZAÇÃO DO SUJEITO
}

Rodrigo Barbosa

Universidade Federal de Juiz de Fora

\section{RESUMO}

Este trabalho investiga as fronteiras e interpenetrações entre a ficção e o real (entre verdade e mentira) nas narrativas de si. Observa a distinção aristotélica entre cronistas e poetas; a "literariedade condicional" de textos referenciais e a "literariedade constitutiva" de textos ficcionais, conforme Genette; a divisão de Cosson entre "império dos fatos" e "jardim da imaginação". Analisa a quebra desta dicotomia pela recepção literária de textos autobiográficos e a provocação trazida pelo conceito de autoficção. Avalia a frequente experiência romanesca contemporânea de transitar entre realidade e invenção. Para análise de textos por este prisma, propõe a ideia de uma "linha da ficcionalidade" e discute os romances Tentativas de capturar o ar, de Flávio Izhaki; Baseado em fatos reais, de Delphine de Vigan; A resistência, de Julián Fuks. Questões sobre a ficcionalização do sujeito, em suas narrativas de vida, são abordadas: a autoficcionalização no cumprimento de seus papéis sociais; a ação do inconsciente nas escolhas narrativas; a invenção da memória. São referenciados autores como Aristóteles, Roland Barthes, Philippe Lejeune, Serge Doubrovski, Mikhail Bakhtin, Gérard Genette, Philippe Gasparini, Silviano Santiago, Eurídice Figueiredo, Evando Nascimento, Manuel Alberca, Anna Faedrich, Rildo Cosson.

PALAVRAS-CHAVE: Ficção. Autoficção. Autoficcionalização. Linha da ficcionalidade. 
A vida é uma farsa que todos têm de representar.

Rimbaud

\section{0 embarque}

Quem é este que se posiciona diante da tela em branco do computador e começa a escrever? Que tem ao seu lado cadernos de anotações de suas leituras sobre o que outros escreveram, em textos "classificados" como acadêmicos e em textos "classificados" como literários, sobre o homem e as escritas de si? Que percebe que seus projetos, tanto no campo da escrita crítica como no da criação narrativa ficcional, estão cada vez mais "contaminados" pelo mistério e pela riqueza que se revelam (e, principalmente, se escondem) por detrás de palavras-conceito como realidade; ficção; verdade; mentira? Há alguma possibilidade de que este que se posiciona diante da tela em branco do computador e começa a escrever seja o mesmo sujeito que se apresenta a quem agora lê estas linhas?

Certamente não, adianto-me às conclusões (poucas) a que chegarei. Assim como não será este, o das linhas que você lê, aquele destas mesmas linhas, se porventura revelado a outro leitor. Somos vários, portanto, e carregamos todos nossas verdades e nossas mentiras: as que nos enredam nas nossas experiências vivenciais, físicas e emocionais; as que conformam a nossa memória; as que aparecem através das palavras que brotam do gesto de apertar estas teclas, palavras que surgem neste exato momento em que teclo: "o autor não sabe o que vai escrever enquanto não escreve efetivamente" (FIGUEIREDO, 2015, p. 49).

Mas vamos aos poucos, com cautela, sustendo o atropelo das palavras, antes que nos traiam ainda mais do que já o farão normalmente. É preciso escolher uma rota mesmo sabendo que as marés e possíveis ventos e tempestades vão nos conduzir a outros portos. Tomemos os cadernos de anotações como nossa carta de navegação. E, para que o leitor e a leitora nos acompanhem na viagem de forma um pouco mais confortável, uma ligeira informação sobre o que são tais cadernos.

Alguns deles reúnem, espalhadas em suas páginas, indicações e referências de autores que, em algum momento e cada qual à sua maneira, refletiram sobre os caminhos da ficção e da realidade nas narrativas, indagando de seus distanciamentos e seus entrecruzamentos. As linhas destes cadernos me conduzem a buscar diálogos entre textos de Aristóteles, 
Roland Barthes, Philippe Lejeune, Serge Doubrovski, Mikhail Bakhtin, Gérard Genette, Philippe Gasparini, Silviano Santiago, Eurídice Figueiredo, Evando Nascimento, Manuel Alberca, Anna Friedrich, Rildo Cosson.

Já as anotações feitas em outros três cadernos lembram trechos e reações em mim provocadas por três romances contemporâneos, lançados no Brasil entre 2015 e 2016: Tentativas de capturar o ar, do brasileiro Flávio Izhaki, Baseado em fatos reais, da francesa Delphine de Vigan e A resistência, do brasileiro, filho de argentinos, Julián Fuks - cada um com seus percursos instigantes entre o real e o ficcional, entre a verdade e a mentira, entre o "eu" e o "outro", os "outros". É este o cesto, rico em provocações e descobertas, habitado pelos tais cadernos de anotações, que nos servirá de bússola possível nesta rota de indagações, auxiliando na missão de tentar elaborar itinerários por onde siga a narrativa que está começando aqui. Vamos a eles.

\section{Derrubar paredes, quebrar janelas}

Estavam instalados de forma mais ou menos confortável em salas razoavelmente distintas os textos ficcionais e os referenciais. A sala dos poetas; a sala dos cronistas. Uma divisão aristotélica:

De tudo o que dissemos, resulta claramente que o papel do poeta é dizer não o que aconteceu realmente, mas o que poderia ter acontecido na ordem do verossímil ou do necessário. Pois a diferença entre o cronista e o poeta [...] é que um diz o que aconteceu, o outro o que poderia ter acontecido (ARISTÓTELES citado em GASPARINI, 2014, p. 218). ${ }^{1}$

Outra metáfora pode ser chamada para batizar as salas: aquela de Rildo Cosson que distingue o discurso jornalístico (outro tipo de narrativa calcada no referencial) e o discurso literário, situando o primeiro no "império dos fatos" e o segundo no "jardim da imaginação". ${ }^{2}$ A parede que divide as salas parece assim nítida e sólida: de um lado, o real; do outro, a invenção. Será mesmo? Mas e quando encontramos atributos poéticos, literários, estéticos, em um texto jornalístico, em um texto de história, em um ensaio, em uma crônica? Philippe Gasparini lembra que Gérard Genette admite uma "literariedade condicional" (GASPARINI, 2014, p. 181) de certos textos referenciais, condição esta dada pelo receptor, pelo público, pela avaliação subjetiva e afetiva que o leitor estabelece com o texto. Assim, ele mudaria de sala? Para Genette parece que não, pois, a esta literariedade condicional da narrativa referencial se contraporia uma 
"literariedade constitutiva" da narrativa ficcional. Como bem observa Gasparini, a oposição aristotélica permanece em Genette: o texto ficcional é literário em sua gênese enquanto o texto referencial pode adquirir status literário sob determinada condição ou situação.

É na sala "império dos fatos" que Gasparini vai buscar exemplos capazes de furar a parede: "Ora, há mais de 20 anos, existem escritores, e não dos menores, para contestar esta clivagem e reivindicar que seus textos autobiográficos beneficiem-se de uma recepção literária incondicional" (GASPARINI, 2014, p. 182). Ele refere-se às escritas de si de autores como Rousseau, Goethe, Chateaubriand e Sartre, por exemplo, mas também a todos os que utilizam recursos romanescos para tratar de referências do real. O surgimento do romance, com sua voracidade antropofágica e parodista dos outros gêneros, seu caráter múltiplo (como destacou BAKHTIN, 2010, p. 399), certamente contribuiu muito para embaralhar as salas de Aristóteles... mas isto seria assunto para outro ensaio, cais de partida para outra viagem, diferente da que realizamos aqui.

Voltemos à nossa carta de navegação. O que nos importa a esta altura do percurso é perceber que muito se pode encontrar de literário (e ficcional) em narrativas supostamente referenciais, como são os casos das autobiografias, das biografias, das memórias, dos diários, mas também de textos científicos, jornalísticos e de outras naturezas, aparentemente bem mais próximas do império dos fatos. O que nos interessa é tentar entender como e por que a parede foi sendo derrubada - e o que emerge neste espaço.

Philippe Lejeune, em seu "pacto autobiográfico" (LEJEUNE, 2008), ergueu uma casa com nove janelas de vidro. Duas estavam fechadas. Serge Doubrovski jogou uma pedra e estilhaçou a janela que Lejeune não soube abrir (a outra, por indeterminada, manteve-se fechada). $\mathrm{O}$ estrago foi grande. Cacos se espalharam por todo lado e atingiram muita gente. Desde aquela quarta capa de Fils, a pedra-palavra "autoficção" provoca inquietação, para usar um termo mais brando, e é debatida nas mais variadas instâncias acadêmicas e literárias. Parece-me curioso (e certamente rico de significados) que o termo tenha surgido assim mesmo, jogado feito uma pedra, sem que Doubrovski tenha dedicado a ele mais do que poucas linhas, no espaço da publicação que apresenta (e também divulga, promove) seu romance; sem um constructo que o definisse e defendesse, além de algumas frases soltas: 
Autobiografia? Não, esse é um privilégio reservado aos importantes desse mundo, no crepúsculo de suas vidas e num belo estilo. Ficção, de acontecimentos e fatos estritamente reais; se preferirmos, autoficção, por ter confiado a linguagem de uma aventura à aventura da linguagem (DOUBROVSKI, 1977, p. 10).

A janela fechada que a pedra de Doubrovski quebrou, a "casa cega" como o próprio Lejeune a definiu, deveria se abrir para um romance em que o nome do autor e o nome do personagem fossem os mesmos. O construtor da casa não enxergou espaço onde coubesse esta situação: "Cego estava eu", admitiu, depois, o autor, "recusei a ambiguidade... No entanto essa é uma prática comum” (LEJEUNE, 2008, p. 58). Autor e personagem confundem-se, como os Doubrovski. E também confundem, provocam, o leitor. Será mesmo um romance, uma ficção de "acontecimentos e fatos estritamente reais"? Onde está a verdade? Onde está a mentira? A sala por detrás da janela, agora aberta, mistura o império dos fatos e o jardim da imaginação, promove uma reunião animada entre poetas e cronistas.

(Aqui, um ligeiro parêntese, para uma ressalva: a casa de Lejeune, a das nove janelas, é erguida sobre a ideia de um "pacto" entre autor e leitor. Um contrato no qual se informa de maneira clara para o receptor se o que ele está a ler é um romance ou é uma autobiografia. Um pacto romanesco ou um pacto autobiográfico antecedem e conduzem a leitura. Portanto, sem o estabelecimento de um pacto, não há casa, não há janelas abertas ou fechadas. Sem pactos, serão outras as casas e outros os seus mistérios, para além de suas janelas.)

A pedrada da autoficção vai muito além do reconhecimento e da discussão sobre romances (portanto, narrativas que ostentam a "literariedade constitutiva dos textos de ficção") em que o verdadeiro nome do autor é idêntico ao do personagem. Ela acerta as tantas variantes de uma recorrente experiência romanesca contemporânea, em que, junto a uma crescente escolha de escrever sobre si, os escritores o fazem utilizando-se das mais variadas estratégias de desnudamento/ocultamento, de mistura de elementos referenciais e ficcionais, de transitar sem pudor entre a mentira e a verdade, de reconhecer, enfim, seja no texto mais próximo dos fatos, seja no mais próximo da imaginação, que sempre há verdade na mentira e sempre haverá mentira na verdade. E de reforçar este jogo.

Os debates sobre a autoficção que saem dos livros para minhas anotações reforçam o sentimento de que não há um discurso narrativo integral e autenticamente verdadeiro ou falso, que todos estão (e sempre 
estiveram) transitando entre as emergências dos fatos da vida e as necessidades (imposições) da invenção. O que traz peso e impulsiona o debate sobre o neologismo de Doubrovski não é apenas a força de um "movimento" de escritas de si nos diferentes espaços romanescos e em países diferentes, inclusive na literatura brasileira contemporânea. É também a provocação à consideração de que estivemos sempre, em maior ou menor escala, nos “autoficcionando". O que leva Gasparini a indagar (e não responder claramente) se a palavra autoficção "corresponde a uma categoria que já existia e só estava esperando ser identificada ou designa um meio de expressão totalmente novo, próprio a nossa época". Enfim, trata-se do "nome atual de um gênero ou o nome de um gênero atual"? (GASPARINI, 2014, p. 183-184).

Ao final do artigo em que levanta esta indagação (também contida no próprio título do artigo: “Autoficção é o nome de quê?”), o autor escapa de uma resposta direta e "classifica" o termo como uma "palavra-teste, palavra-espelho, que nos devolve as definições que lhe atribuímos". Para ele, "a sedução do termo se deve à sua ambiguidade, a seu mistério. Todos podem se apropriar dele ou rejeitá-lo em função de sua própria identidade narrativa e de sua própria mitologia estética" (GASPARINI, 2014, p. 218). Também Evando Nascimento recusa a tentativa de converter autoficção em um novo gênero, "reduzindo-se a clichês e ideias fixas". Ele lembra, sobre a pedra-palavra que rompeu a janela cega de Lejeune, que "a graça e o frescor da invenção doubrovskiana é ter sido uma provocação literária ao papa do sacrossanto gênero da autobiografia, Lejeune". Faço coro com ele quando afirma: "Converter autoficção num gênero com características definidas e repetidas à saciedade, parece-me uma traição ao impulso inventivo original" (NASCIMENTO, 2010, p. 194-195).

A ambiguidade, como bem destacou Gasparini, e aprofundaram Manuel ALBERCA (2007) e Anna FAEDRICH (2015), é marca desta aventura de fazer ficção de acontecimentos e fatos estritamente reais. Há uma boa dose de ironia na frase-definição original do homem que atirou a pedra e ela ressalta justamente a indecidibilidade do termo: se é uma ficção, como os fatos poderiam ser estritamente reais? Um "autoficcionista", assumido ou não (com ou sem pactos), ao "abolir os limites entre o real e a ficção", está querendo "confundir o leitor e provocar uma recepção contraditória da obra" (FAEDRICH, 2015, p. 57). Por isso, escolho o caminho sugerido por Eurídice Figueiredo, que valoriza o debate sobre o termo por ampliar horizontes de percepção sobre novas 
narrativas contemporâneas, mas que prefere olhar "exercícios de autoficção" como mais uma das possibilidades do "mais maleável dos gêneros" (BAKHTIN, 2010, p. 403), o romance: "considero que a autoficção deve ser pensada como um elemento que faz parte do processo de transformação do romance no último quarto do século XX e que se fortalece no novo século" (FIGUEIREDO, 2013, p. 66).

\section{Flutuar na linha da ficcionalidade}

Escolha feita, agradeço a contribuição de todos e vamos em frente! A parede que separava as salas aristotélicas dos fatos (e seus cronistas) e da imaginação (e seus poetas) ruiu. A separação entre a literariedade constitutiva e a condicional de Genette se dissolveu diante de olhares generosos e espantados de leitores para textos aparentemente não literários. A janela cega de Lejeune abriu-se à força e revelou um novo espaço, ou espaços que estavam lá, escondidos, repletos de possibilidades. E eles são espaços abertos, que não aceitam confinamentos em salas fechadas, separadas por palavras-caixa. São espaços que não toleram reverência sagrada a rótulos dicotômicos. Não é fácil transitar nesses espaços, costuma não ser confortável pensar além das caixas (e estão aí as bolhas e os algoritmos da internet, enclausurando e dividindo as pessoas, para dramatizar esta dificuldade, este desconforto).

Mas creio que devamos sempre tentar. Imagino este novo espaço como um campo aberto, sem barreiras e sem paredes, e uma linha que se colocasse a percorrê-lo, de uma ponta (que não vemos) a outra (que também não visamos). $\mathrm{O}$ campo se estende e se distende além dos nossos limites de visão, mas sabemos que, de um canto a outro, há uma espécie de percurso entre dois marcos, difusos, mas existentes (ao menos na nossa intuição).

Chamemos a um deles de marco zero e ao outro de marco cem (apenas para demarcar a existência de um espaço aberto entre eles). Imagino agora este espaço, este percurso, coberto de textos. Mais próximos do marco zero estão textos outrora presos na sala dos cronistas de Aristóteles, a sala do império dos fatos. Mais próximos do marco cem está a turma da sala dos poetas, está o jardim da imaginação. Entretanto, não há textos $\boldsymbol{n} \boldsymbol{o}$ marco zero nem no marco cem. Sequer enxergo os dois marcos, aliás. O que aproxima ou distancia os textos das pontas da linha, desta "linha da ficcionalidade", é a intensidade com que a linguagem (ou melhor, as linguagens) que eles escolhem e as referências que usam se aproximam 
de linguagens e de referências "reconhecidas" como mais próximas do real ou da invenção; do "verdadeiro" ou do "mentiroso", se preferirem.

Chegando mais perto dessas narrativas, observo que os elementos que podem revelar uma intensidade de linguagem mais tendente a uma ponta ou a outra se integram, se alteram e mesmo se confundem. Assim, um texto jornalístico que se coloca mais perto do marco zero porque utiliza uma linguagem em ordem direta, despida de adjetivos, com um vocabulário simplificado, não escapa, por exemplo, de uma descrição de cenário em que o autor precisa convocar recursos e palavras que conduzam a imaginação do leitor a "ver" o que ele descreve. Em outra parte da linha, que caminha para o marco cem, encontro um texto poético, que experimenta construções frasais inusuais e subverte sentidos de palavras, mas que só provoca o efeito que busca porque surpreende um leitor acostumado às construções comuns e que conhece um sentido "real" daquelas palavras.

Assim também acontece com as referências. Quanto mais comprováveis, atestáveis, mais puxam o texto em direção ao marco zero. Mas o que é documentado e comprovado hoje o será amanhã? Pense na ciência, na história. O que aquele papel me diz sobre o passado da minha família é capaz de traduzir a minha história com ela? Ou tenho de completar o papel com minha memória e a minha imaginação? Por sua vez, quanto mais inventadas, criadas por um autor que nunca as viu ou vivenciou, mais as referências colocam o texto no rumo do marco cem. Mas é possível inventar, criar um fato, um acontecimento que não envolva alguma experiência de seu autor com o mundo, externo ou interno?

Olhando ainda mais "para dentro" desses textos, posso ver também que eles nunca estão quietos, plantados sobre um ponto da linha. Enquanto os lemos, eles flutuam nos dois sentidos do percurso, pois ora a "linguagem da aventura" cede espaço à "aventura da linguagem", ora ocorre o movimento contrário. Eles flutuam entre os dois marcos porque ora acreditamos nas referências, ora desconfiamos delas (com ou sem pacto prévio). Flutuam, enfim, porque cada leitor viverá com o texto a sua experiência pessoal de reconhecimento da linguagem (das linguagens) e das referências.

Os três romances escolhidos para me acompanhar nesta viagem (e para apontar trilhas por onde ela pode se enveredar) ocupam, na minha experiência de leitura, lugares distintos ao longo da linha, embora todos estejam, vamos dizer assim, no "trecho central" do percurso, aquele em que se embaralham ainda mais o real e a invenção, tanto no plano da 
linguagem quanto na apresentação e identificação das referências. Estão no trecho mais "indecidível" entre o marco zero e o cem. Mas não estão exatamente no mesmo ponto, como, aliás, creio que texto nenhum, ainda mais um romance, está.

Entre os três, vejo A resistência, de Julián Fuks, mais na "banda baixa" deste trecho central da linha, embora se leia na folha de rosto que "os personagens e as situações desta obra são reais apenas no universo da ficção; não se referem a pessoas e fatos concretos, e não emitem opinião sobre eles" (FUKS, 2015, folha de rosto). Embora esta inserção do romance de Fuks no "universo da ficção" esteja afirmada (ainda que de forma quase escondida) no meio da folha de rosto, qualquer pesquisa ligeira sobre a vida do autor revela as "coincidências" com o perfil do protagonista de $A$ resistência (a origem argentina, a família exilada, a profissão dos pais, o irmão adotado...). O desenvolvimento da trama nos aproxima do real com referências a conhecidos fatos históricos, especialmente a ditadura argentina e suas Mães da Plaza de Mayo.

Já Tentativas de capturar o ar, de Flávio Izhaki, estaria posicionado mais na "banda alta" da linha, a que tende à invenção. Ainda que utilize recursos narrativos que trazem o leitor para um mundo da realidade (tais como um diário, uma "nota do editor", arquivos de internet com transcrição de entrevistas, citações de fatos e pessoas reais), não há convergências claras entre a vida do autor e o narrador principal (que está morto), os personagens são inventados (mesmo que se possam estabelecer semelhanças entre Antônio Rascal, o escritor biografado do romance, e outros escritores brasileiros), os acontecimentos são ficcionais, pois não reconhecemos referências que os aproximem de histórias "reais", conhecidas.

Entre os dois seria o lugar de Baseado em fatos reais, de Delphine de Vigan, pois, embora a autora ocupe o espaço da janela quebrada, ao nomear seu personagem principal com o próprio nome e ao fazer diversas referências aparentemente coincidentes entre as duas (ambas escritoras, ambas vindo de um livro de sucesso etc.), a trama apresenta uma vilã misteriosa (a ghost-writer L.), caminha para um clima de tensão e suspense próximos da fíç̧ão e faz questão de estimular a dúvida do leitor sobre os tais "fatos reais" em que o romance seria "baseado". "Quando uma verdade tem mais de cinco linhas, é um romance", lembra a personagem Delphine, citando Jules Renard (VIGAN, 2015, p. 57). "Meu objetivo foi fazer o leitor se perder nesta confusão entre ficção e realidade", confessa a autora Delphine, em entrevista de lançamento do livro (VIGAN, 2016, p. 1). 
Há muitas abordagens possíveis sobre os romances e seus lugares no campo aberto onde a linha liga realidade e invenção. Nosso espaço aqui é limitado. Fiquemos com a percepção de que os três autores, como admite Vigan, escolhem brincar com as pontas da linha, como quem faz um novelo, para depois fabricar sua teia de forma a fazer deste jogo de aparências entre fatos reais e ficção uma das estratégias para enredar o leitor. "Assim é, se lhe parece", parecem dizer a seu público, como PIRANDELLO (2011). Fazem questão de não propor pactos que não sejam os que venham a realçar sua ambiguidade. Há uma intenção de flutuar fora das caixas e dos rótulos e, mais do que isto, de fazer desta indecidibilidade sua matéria-prima para provocar (e seduzir) o leitor.

É justo neste ponto que a nossa carta de navegação aponta novos rumos possíveis. Há uma intenção, um desejo, por detrás da fabricação da narrativa. Para que ela se realize, a quebra das paredes e do vidro da janela oferece ao autor uma liberdade e um risco. A liberdade de se apropriar sem pudores de recursos de linguagem que estejam disponíveis em qualquer ponto da linha. A liberdade de lançar mão de referências comprováveis e inventadas. A liberdade de não temer embaralhar verdade e mentira e até de fazer dessa mistura uma estratégia narrativa. A liberdade, enfim, de criar sem limites.

E o risco de não saber o que fazer com tanta liberdade.

\section{Viver como ficção}

Mas aqui, no curso deste ensaio, não sou assim tão livre. "Não sou eu quem me navega; quem me navega é o mar", sopra PAULINHO DA VIOLA (1996) nos meus ouvidos. E, "como nem fosse levar", ele me carrega a um novo oceano. Volto ao caderno atrás de pistas que me iluminem a rota, desconfiado de que há um mar revolto pela frente, mas que não pode ser evitado nesta busca de possíveis respostas a perguntas que motivaram a viagem: Quem é este que escreve? O quanto ele se aproxima e se distancia do outro que, antes de escrever, sentou-se ao computador? A que distância dos marcos suas narrativas (seus "textos"), como este que você lê, se colocarão naquela linha?

Preciso voltar atrás, olhar para a popa e investigar que marés me trouxeram a este novo oceano antes de entender o que ele me apresenta. Em sua liberdade de flutuar sobre a linha do real e da invenção (a nossa "linha da ficcionalidade"), Fuks e Vigan (especialmente esses dois) colocaram a si como personagens de seus romances. Ela, com seu próprio 
nome, Delphine; ele, identificando-se como Sebastián (e não como Julián), uma única vez, quase ao final de $A$ resistência, como se quisesse dizer ao leitor, com este contraponto cirúrgico: "este personagem, que você pensou que era eu, pode não ser". De qualquer forma, elaborando a questão do nome próprio por um caminho ou por outro, ambos fizeram de seu texto uma ficção de si.

Mas o fizeram não apenas porque exploraram intencionalmente a ambiguidade, a ausência de limites entre realidade e invenção, entre o ser de verdade e o personagem do romance. A ficção se estabeleceria mesmo que não houvesse a intenção e que não se lançasse mão da estratégia, pois uma vida colocada em texto, ainda que repleta de índices de realidade, é uma outra vida. Quem está no texto nunca é quem escreve. "O eu que escreve o texto, também, nunca é mais do que um eu de papel”, dizia Roland BARTHES (1988, p. 74). E, assim, quando utiliza dos recursos de linguagem e busca referências para trazer o real para o texto, o autor inscreve na página um "outro real", que, por sua vez, será recriado pelo leitor em cada ato de leitura. A Delphine real não é outra em relação à Delphine do papel apenas porque decidiu produzir uma ficção de si, uma autoficção. Ela é outra porque é feita de outra natureza, a partir do momento em que se pôs em linguagem. "O sujeito narrado é um sujeito fictício justamente porque é narrado, é um ser de linguagem", destaca Eurídice FIGUEIREDO (2013, p. 67). Assim, não há identidade possível entre a Delphine autora e a Delphine personagem, a real e a de papel, apenas alguns possíveis índices de aproximação.

Olhando de outra forma, é possível ver que essa distância se dá no próprio gesto de colocar a narrativa em texto. $\mathrm{O}$ autor escolhe palavras e organiza frases - e é escolhido e organizado por elas quando escreve. "O autor conhece as palavras, é claro, mas não sabe que palavras vai empregar, não tem um controle absoluto sobre o processo. $\mathrm{O}$ autor projeta e controla, sem dúvida, mas muita coisa lhe escapa, foge à sua intenção", afirma Eurídice FIGUEIREDO (2015, p. 49-50). Ou, dito de uma forma mais radical, como era natural em Clarice Lispector: "É curiosa a sensação de escrever. Ao escrever não penso no leitor nem em mim: nessa hora sou - mas só de mim - sou as palavras propriamente ditas" (LISPECTOR, 1978, p. 78). Não há como escapar: quando escrevo, sou outro.

Só quando escrevo? Leio e vejo em vídeo as entrevistas de Fuks e Vigan, assim como a de Izhaki, e me pergunto: quem são aqueles que 
respondem às perguntas, que falam sobre si e sobre suas obras? Seriam eles outras ficções de Julián, Delphine e Flávio?

Quem me responde é Evando Nascimento, e justamente esta anotação do caderno me encoraja e me estimula a seguir a viagem e a encarar as novas águas: "O mais perturbador não é ver a vida convertida em romance, poesia, drama ou ensaio (isto a literatura sempre fez, com os mais diversos recursos), mas perceber que o próprio tecido vital está infestado de ficcionalidade" (NASCIMENTO, 2010, p. 200, grifo meu).

Uma nova onda ameaça virar o barco e eu me agarro aos cadernos. Não apenas nas narrativas textuais, com deliberada intenção ou por uma inescapável alteridade; não somente no papel: ficcionalizamos a vida? Somos seres de ficção? Respostas diversas podem brotar de diferentes ângulos de abordagem, em especial por visadas da sociologia e da psicanálise. Para não fugir do roteiro proposto, escolho dois apontamentos que me parecem ricos em aproximações com os pontos de interesse abordados no começo deste texto. O primeiro se relaciona aos papéis que representamos, nossas "microperformances", a teatralidade das relações sociais, conforme destacou Evando Nascimento no trecho de seu artigo sobre autobiografia e autoficção em que faz uma leitura do romance $O$ filho eterno, de Cristóvão Tezza (NASCIMENTO, 2010, p. 202). O segundo, à nossa incapacidade de domar o inconsciente e, por consequência, de produzir qualquer narrativa integralmente autêntica.

No texto-palestra "Meditação sobre o ofício de criar", Silviano Santiago trata de sua trajetória de escritor e sua "preferência pelos dados autobiográficos e a contaminação do discurso autobiográfico pelo ficcional" (SANTIAGO, 2008, p. 176). E conta como, desde menino, marcado pela morte prematura da mãe, fabulava fatos de sua vida e criava suas "falas ficcionais" (SANTIAGO, 2008, p. 176, grifo meu). Em suas idas obrigatórias ao confessionário, diante do padre, confessa agora: "Mentia. Ficcionalizava o sujeito - a mim mesmo - ao narrar os pecados constantes da lista" (SANTIAGO, 2008, p. 177). A narrativa inventada pelo menino "assumia uma fala híbrida - autobiográfica e ficcional - verossímil" (SANTIAGO, 2008, p. 177). Ele representava seu papel, tornava-se personagem de si mesmo, para cumprir sua obrigação religiosa, sua missão social - e convencer o padre.

Como ele, em todas as idades, compomos nossos personagens em teatros de um eu que se ficcionaliza, que se traveste em outros. Que se autoficcionaliza. Autoficção que, no texto do papel ou nas mais diferentes 
performances narrativas sociais, "nos libera a reinventar a mediocridade de nossas vidas, segundo a modulação que eventual e momentaneamente interessa", constata Nascimento, ao apontar "mais um fenômeno da hibridização do real", marca do nosso tempo capturada pela autoficção, "fazendo com que sejamos sempre mais de um, mesmo ou sobretudo quando ostentamos um mesmo rosto, aparentemente uma única feição" (NASCIMENTO, 2010, p. 201).

Na base etimológica da palavra "fícção", no latim, está o verbo fingere, em seus significados de afeiçoar, modelar, plasmar, fabricar. Quando nos "autoficcionalizamos" (e o fazemos todo o tempo) estamos, feito um escultor, a modelar, a dar feição a outros de nós. A fabricar nossos personagens autoficcionais, criando suas falas híbridas, no texto e na vida, de forma a produzir as narrativas que nos parecem eficazes ao teatro social, que nos auxiliem a seduzir o outro para os nossos mais diversos objetivos, mas, fundamentalmente, para sobreviver e buscar algum tipo de felicidade. Somos sempre mais de um, ainda que ostentemos um mesmo rosto.

O Rodrigo que está nesta página que você lê, como já demonstramos, não é o Rodrigo que está sentado diante da tela do computador e digita/digitou estas palavras. E este também é um outro, um navegante em busca de respostas para as questões que se colocou ao início desta jornada. É aquele que gostaria de ver este texto publicado nesta revista (e pensa nisto quando escreve, por que negar?). E é também outros, que surgirão após a conclusão desta viagem e que estarão marcados por elas, em cada nova narrativa que vierem a construir.

Seguindo a viagem, estes Rodrigos percebem que nosso "tecido vital" também é "infestado de ficcionalidade" porque jamais o dominamos plenamente. Nossas reações, nossas emoções, nossos impulsos percorrem zonas do corpo que a medicina e a psicanálise (e hoje a engenharia genética, a neuropsicologia) tentam mapear, decifrar e domar, mas, ainda que avancem no diagnóstico e desenvolvam técnicas e tecnologias (químicas, físicas, terapêuticas), estão longe de nos colocar como sujeitos de si, donos absolutos de nós mesmos. "O sujeito não controla seu inconsciente, não controla sua fala, não podendo, portanto, ter qualquer certeza sobre a autenticidade do que diz", observa Eurídice FIGUEIREDO (2015, p. 59), ao analisar a relação de Roland Barthes consigo mesmo, em especial com seu corpo (sua dor de cabeça e sua sensualidade).

Quero dizer algo e posso estar dizendo algo diferente, traído pelo inconsciente e pelas palavras que ele escolhe. Quem é o narrador au- 
têntico, aquele que quer dizer ou aquele que diz? Nenhum dos dois. De "autêntica" só há a narrativa que está posta (e a forma com que você a recebe). Mesmo em nossos diálogos internos, em nosso fluxo de pensamento, em nossas silenciosas conversas com Deus, não controlamos a "narrativa". E um outro ser de ficção se instala dentro de nós, apesar de nós, para nosso espanto.

Um outro bom exemplo de nosso tecido vital infestado de ficcionalidade pode ser encontrado na memória: quando a visitamos, estamos sempre a inventar. Em A resistência, Fuks retrata a história de um jantar fracassado na casa de seus pais, uma noite cujo relato visual ("meus pais prostrados diante da mesa, seus ombros curvados, a comida fumegante ainda intocada") é feito a partir de um único registro: a lembrança do menino Sebastián/Julián. Ao descrever a cena (e rever os pais com a memória), ele sabe que a recria: "Sei que dramatizo quando assim os vejo, sei que dou ao caso um peso exagerado, um peso que os relatos deles jamais comportaram. Mas acho que dramatizo este peso porque posso senti-lo, porque de alguma maneira o entendo, ou creio entendê-lo" (FUKS, 2015, p. 51-52).

Fuks fotografa este fragmento de sua história de vida (este seu "biografema", conforme BARTHES, 2005, p. xvii) com a dramaticidade, o "peso", que escolhe dar hoje para contar a sua trajetória e a de seus pais. Um peso que ele julga sentir (agora) porque entende (hoje) o seu significado na vida do casal e de sua família. Ao revisitar a cena, ele recolhe o fragmento e dá a ele o sentido que quer, adequado à sua atual percepção de si, ficcionalizando o menino que foi. "De todo modo, reinventamos nossa vida quando a rememoramos", escreve DOUBROSVSKI (2014, p. 123-124).

A narrativa de si, composta dos personagens que criamos para exercer nossos papéis, feita de falas intencionais e de vozes que nos surpreendem, moldada pela invenção da memória, “é sempre modelagem, roteirização romanesca da própria vida” (DOUBROVSKI, 2014, p. 124).

\section{Sete pistas (Não há cais)}

Faço a volta, pois a carta de navegação aponta um retorno ao cais. Guardo os cadernos, mas não há cais. Quando a viagem termina, só resta a viagem. Aquele que se posiciona diante da tela do computador, agora cheia de palavras, tornou-se outro, um "ser de linguagem". Que será aquele que você quiser, em seu gesto de leitura. Assim como será um es- 
tranho para mim quando ler o que foi escrito neste ensaio, quando eu me encontrar com este eu de papel, ser de linguagem que brotou de mim, de minhas intenções, de minhas referências anotadas, de minhas perguntas e de palavras inesperadas, de falas descontroladas, de sustos.

Quem agora encontra este outro de papel é aquele que vai empreender novas viagens narrativas, tanto no campo da crítica como na produção ficcional. Aos seus olhos, este relato de viagem revela algumas pistas novas para as aventuras que virão:

Estou livre para flutuar sobre a "linha da ficcionalidade", percorrê-la, entre os marcos do real e da invenção, da forma que me parecer mais interessante, divertida, rica, estimulante - e também da forma que me for possível e do jeito que meu corpo me quiser levar.

Sempre haverá uma "memória narrativa" (de fatos e invenções) nas escolhas de linguagens e referências que faço. Não devo fugir dela; não devo superestimá-la.

Não devo recusar (nem valorizar ingenuamente) o fato de que sou sempre "mais de um" e que esta "pluralidade" - agora vejo com mais nitidez - está na gênese das minhas narrativas.

Por trás destas escolhas, estão os papéis do teatro social que eu julgo ser necessário interpretar (ou os que fui levado a interpretar), diante das circunstâncias de minhas relações com os outros e comigo mesmo.

Na gênese de minhas escolhas narrativas, estão e estarão "objetivos" em relação a alguém. O lugar que elas vão ocupar entre os dois marcos da linha, as linguagens e referências que vão buscar, são orientados para o outro. O que cada narrador quer, ao fim e ao cabo, com sua narrativa, é seduzir. E é por esta razão principal que ele se autoficcionaliza (no papel e na vida). "É o destinatário, o outro, a exterioridade, que transforma o sujeito em autor" (KRISTEVA citado em FIGUEIREDO, 2015, p. 22).

Mas, para obter êxito em minha tarefa de sedução, devo construir narrativas "eficazes". É preciso convencer o meu interlocutor, o outro. É preciso convencer você. Minhas falas híbridas entre o real e a invenção devem parecer verossímeis e, como o menino Silviano diante do padre-confessor, trazer uma "consistência de experiência", que lhes garanta a "veracidade" ou a "autenticidade" aos olhos de quem as recebe (lê, escuta, vê) (SANTIAGO, 2008, p. 177).

É claro que existem limites para o flerte com o ficcional num texto crítico como este (assim como o bom senso impõe restrições ao uso de 
uma linguagem "excessivamente" referencial num texto de ficção, como o de um romance). Alguns códigos se impõem. Devem ser considerados, respeitados. Mas podem ser subvertidos. E, se a subversão for feita com graça e pertinência, pode contribuir muito para que a narrativa cumpra com eficácia a missão que a fez nascer.

São sete pistas, mas é melhor parar por aqui, que sete é conta de mentiroso - e de mentirosos e mentiras este texto já está carregado. É tempo de abrir outros cadernos para receber outras anotações. Há muitos outros mares para singrar. Sinto, por exemplo, que é preciso mergulhar nas águas da alteridade (que apenas respingaram aqui), remar em busca do oceano misterioso do inconsciente, tentar achar as ilhas onde existem sereias para que me ensinem o seu canto sedutor, para debater as estratégias dos narradores na "conquista" de seu(s) público(s).

Tudo para que o poeta e o cronista de Aristóteles se encontrem (quem sabe? algum dia?) na mesma sala e, juntos, numa só narrativa, digam a alguém "o que aconteceu" e "o que poderia ter acontecido".

\section{SOME RODRIGOS: A TRAVEL REPORT ABOUT THE FICTIONALIZATION OF THE SUBJECT}

\section{ABSTRACT}

This paper investigates the boundaries and interpenetrations between fiction and reality (between truth and lie) in the narratives of itself. It notes the Aristotelian distinction between chroniclers and poets; the "conditional literariness" of referential texts and the "constitutive literariness" of fictional texts, according to Genette; Cosson's division between "empire of facts" and "garden of the imagination". It analyzes the breakdown of this dichotomy by the literary reception of autobiographical texts and a challenge brought by the concept of autofiction. It evaluates the frequent contemporary romanesque experience of moving between reality and invention. For the analysis of texts under this prism, it proposes the idea of a "fictionality line" and discuss the novels Tentativas 
de capturar o ar, by Flávio Izhaki; Baseado em fatos reais, by Delphine de Vigan; A resistência, by Julián Fuks. Questions about the fictionalization of the subject in his life narratives are addressed: the self-fictionalization in the fulfillment of their social roles; the action of the unconscious in the narrative choices; the invention of memory. Authors are referenced such as Aristóteles, Roland Barthes, Philippe Lejeune, Serge Doubrovski, Mikhail Bakhtin, Gérard Genette, Philippe Gasparini, Silviano Santiago, Eurídice Figueiredo, Evando Nascimento, Manuel Alberca, Anna Faedrich, Rildo Cosson.

KEYWORDS: Fiction. Autofiction. Self-ficcionalization. Fictionality line.

\section{NOTAS}

${ }^{1}$ No original em francês do artigo de Gasparini, "De quoi l'autofiction est-elle le nom?". Disponível em: http://www.autofiction.org/index.php?post/2010/01/02/ De-quoi-1-autofiction-est-elle-le-nom-Par-Philippe-Gasparini. Em nota citando Aristóteles, é utilizada a palavra chroniqueur (e não historien) para traduzir historikos. Esta é também a escolha de outros tradutores franceses do filósofo grego, como Roselyne Dupont-Roc e Jean Lallot. A tradução do artigo para o português, de Jovita Maria Gerheim Noronha e Maria Inês Coimbra Guedes, utiliza a palavra "cronista". Outras traduções da Poética de Aristóteles para o português escolhem a palavra "historiador". Optamos por seguir a trilha "chroniqueur"/ "cronista", por nos parecer mais adequada ao momento (335/322 a.C.) da escrita aristotélica original, quando a história como ciência e a atividade do historiador ainda não haviam sido sistematizadas.

2 "Essa diferença capital entre os dois discursos está representada pela própria metáfora com que os denominamos. Desse modo, se o jornalismo é o império dos fatos, a literatura é o jardim da imaginação. Na metáfora do império estão contidas as ideias de força, domínio e amplidão de territórios que contrastam com a fragilidade e a sacralidade da arte de cultivar as flores da linguagem no jardim da imaginação" (COSSON, 2002, p. 58). 


\section{REFERÊNCIAS}

ALBERCA, Manuel. El pacto ambíguo: de la novela autobiográfica a la autofición. Madri: Biblioteca Nueva, 2007.

ARISTÓTELES. Poética. Tradução de Ana Maria Valente. Lisboa: Fundação Calouste Gulbenkian, 2008.

BAKHTIN, Mikhail. Questões de literatura e estética: a teoria do romance. Tradução de Aurora Fornoni Bernardini, José Pereira Júnior, Augusto Góes Júnior, Helena Spryndis Nazário, Homero Freitas de Andrade. São Paulo: Hucitec, 2010. BARTHES, Roland. O rumor da língua. Tradução de Mário Laranjeira. São Paulo: Brasiliense, 1988.

. Sade, Fourier, Loyola. Tradução de Mário Laranjeira. São Paulo: Martins Fontes, 2005.

CAZES, Leonardo. Fenômeno de vendas, Delphine de Vigan mistura autoficção e thriller psicológico. O Globo, Rio de Janeiro, Segundo Caderno, p. 1, 6 set. 2016. COSSON, Rildo. Romance-reportagem: o império contaminado. In: CASTRO, Gustavo de;

DOUBROVSKY, Serge. Fils. Paris: Galilée, 1977.

DOUBROVSKY, Serge. O último eu. In: NORONHA, Jovita Maria Gerheim (Org.). Ensaios sobre a autoficção. Tradução de Jovita Maria Gerheim Noronha e Maria Inês Coimbra Guedes. Belo Horizonte: UFMG, 2014. p. 111-125.

FAEDRICH, Anna. O conceito de autoficção: demarcações a partir da literatura brasileira contemporânea. Itinerários - Revista de Literatura. Araraquara: FCL/Unesp, n. 40, p. 45-60, jan./jun. 2015.

FIGUEIREDO, Eurídice. Em torno de Roland Barthes: da morte do autor ao nascimento do leitor e à volta do autor. Santa Maria: UFSM, 2015.

. Mulheres ao espelho: autobiografia, ficção, autoficção. Rio de Janeiro:

EdUERJ, 2013.

FUKS, Julián. A resistência. São Paulo: Companhia das Letras, 2015.

GALENO, Alex (Org.). Jornalismo e literatura: a sedução da palavra. São Paulo: Escrituras, 2002. p. 57-70.

GASPARINI, Philippe. Autoficção é o nome de quê? In: NORONHA, Jovita Maria Gerheim (Org.). Ensaios sobre a autoficção. Tradução de Jovita Maria Gerheim Noronha e Maria Inês Coimbra Guedes. Belo Horizonte: UFMG, 2014. p. 181-221. 
IZHAKI, Flávio. Tentativas de capturar o ar. Rio de Janeiro: Rocco, 2016.

LEJEUNE, Philippe. O pacto autobiográfico: de Rousseau à internet. Tradução por Jovita Maria Gerheim Noronha e Maria Inês Coimbra Guedes. Belo Horizonte: UFMG, 2008.

LISPECTOR, Clarice. Um sopro de vida. São Paulo: Nova Fronteira, 1978.

NASCIMENTO, Evando. Matérias-primas: da autobiografia à autoficção - ou vice-versa. In: LAGE, Verônica Lucy Coutinho; NASCIF, Rose Mary Abrão Nacif (Org.). Literatura, crítica, cultura IV: interdisciplinaridade. Juiz de Fora: UFJF, 2010. p. 189-207.

PAULINHO DA VIOLA. Timoneiro. In: . Bebadosamba. São Paulo: BMG Brasil, 1996. 1 CD.

PIRANDELLO, Luigi. Assim é (se lhe parece). Tradução de Sérgio N. Melo. São Paulo: Tordesilhas, 2011.

RIMBAUD, Arthur. Uma estadia no inferno; Poemas escolhidos; A carta do vidente. Tradução de Daniel Fresnot. São Paulo: Martin Claret, 2005.

SANTIAGO, Silviano. Meditações sobre o ofício de criar. Aletria, Belo Horizonte: UFMG, v. 18, p. 173-179, jul./dez. 2008.

VIGAN, Delphine de. Baseado em fatos reais. Tradução de Carolina Selvatici. Rio de Janeiro: Intrínseca, 2016.

Recebido em: 21/08/2017

Aceito em: 07/12/2017 